\section{JURNAL ABDIMAS

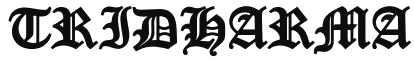

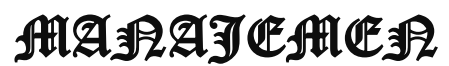

P-ISSN 2615-6849, E-ISSN 2716-070X

Jurnal ABDIMAS Vol. 2,No.3, Agustus 2021,Hal(10-17)

@ Prodi Manajemen Fakultas Ekonomi Universitas Pamulang

Email: abdimasjurnal.unpam@gmail.com Telp: (021) 741-2566

\title{
MANAJEMEN PENGELOLAAN SUMBER DAYA MANUSIA DI KELURAHAN PAMULANG BARAT
}

\author{
Angga Pratama*, Waluyo Jati, Amun Soepandi, Senen, Muhammad Arief \\ Dosen Ekonomi Fakultas Ekonomi Universitas Pamulang \\ Email* : dosen02155@unpam.ac.id,dosen02065@unpam.ac.id, dosen01772@unpam.ac.id, \\ dosen01888@unpam.ac.id, dosen02304@unpam.ac.id
}

\begin{abstract}
ABSTRAK
Salah satu dari tujuan Tridharma Perguruan Tinggi selain Pendidikan dan Penelitian adalah Pengabdian Kepada Masyarakat (PKM). Hal ini diatur dalam Pasal 20 dan 24 Undang-Undang. No. 20 Tahun 2003 tentang Sistem Pendidikan Nasional yang menyatakan bahwa adanya otonomi oleh Perguruan Tinggi, Penelitian Ilmiah dan Pengabdian Kepada Masyarakat. Sebagai pertanggungjawaban kami, maka dalam melaksanakan tugas tersebut telah kami susun laporan kegiatan pengabdian kepada masyarakat.

Dengan mempertimbangkan latar belakang diatas maka kami berinisiatif untuk membentuk Pengabdian Kepada Masyarakat di Kelurahan Pamulang Barat khususnya kepada para pegawai agar dapat meningkatkan kinerjanya dalam rangka pelaksanaan program pengelolaan sumber daya manusia di Kelurahan Pamulang Barat. Tujuan dari pengabdian ini adalah untuk meningkatkan kinerja para pegawai yang diukur dari kemampuan pegawai dalam melakukan pelayanan.

Semua kegiatan yang dilakukan dari pengabdian kepada masyarakat ini diharapkan akan memberikan manfaat baik secara internal (akademisi) dan eksternal (masyarakat umum). Dalam pengabdian kepada masyarakat yang dilakukan oleh dosen serta mahasiswa Fakultas Ekonomi program studi Manajemen Universitas Pamulang diharapkan mampu memberikan solusi dan pembekalan teknis manajemen dalam peningkatan kinerja para pegawai di kelurahaan pamulang barat agar dapat bersaing dalam sebuah organisasi khususnya pegawai kelurahan pamulang barat dalam pentingnya pemanfaatan teknologi tepat guna yang ada di wilayah kelurahan pamulang barat selanjutnya lalu kemudian dilakukan evaluasi secara menyeluruh dan bertahap.
\end{abstract}

\section{Kata Kunci : Sumber Daya Manusia, Kinerja, Teknologi}

\begin{abstract}
One of the goals of Higher Education Tridharma in addition to Education and Research is Community Service (PKM). This is regulated in Articles 20 and 24 of the Law. No. 20 of 2003 concerning the National Education System which states that there is autonomy by Universities, Scientific Research and Community Service. As our responsibility, in carrying out these tasks we have prepared reports on community service activities.

Taking into account the above background, we took the initiative to form Community Service in Pamulang Barat Village, especially for employees in order to improve their performance in the context of implementing human resource management
\end{abstract}




\section{JURNAL ABDIMAS

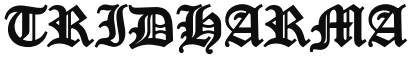 AtA}

P-ISSN 2615-6849, E-ISSN 2716-070X

Jurnal ABDIMAS Vol. 2,No.3, Agustus 2021,Hal(10-17)

@ Prodi Manajemen Fakultas Ekonomi Universitas Pamulang

Email: abdimasjurnal.unpam@gmail.com Telp: (021) 741-2566

programs in Pamulang Barat Village. The purpose of this service is to improve the performance of employees as measured by the ability of employees to perform services.

All activities carried out from community service are expected to provide benefits both internally (academics) and externally (general public). In the community service carried out by lecturers and students of the Faculty of Economics, Pamulang University Management study program, it is expected to be able to provide solutions and technical management provision in improving the performance of employees in the West Pamulang village so that they can compete in an organization, especially employees of the West Pamulang village in the importance of using appropriate technology. the existing use in the area of West Pamulang sub-district is then carried out a thorough and gradual evaluation.

\section{Keywords : Human Resources, Performance, Technology}

\section{PENDAHULUAN}

Permasalahan yang tengah menggurita dalam kehidupan bermasyarakat di Indonesia tidak saja merupakan tanggung jawab Pemerintah akan tetapi juga sudah menjadi tanggung jawab seluruh bangsa Indonesia. Karenanya yang dibutuhkan saat ini adalah solusi yang dapat membantu dalam mengatasi permasalahan yang telah diuraikan di atas. Secara sederhana dapat dikatakan bahwa salah satu solusi yang dapat dilakukan untuk dapat keluar dari masalah terumit yang dihadapi pemerintah saat ini adalah dengan menumbuhkan dan membentuk karakter kewirausahaan sosial pada setiap lapisan indidvidu di masyarakat, terutama generasi muda yang merupakan tulang punggung bangsa (Ayob et.al., 2013; Utomo, 2014; Reginald dan Mawardi, 2014; Sofia, 2015).

Pembangunan merupakan suatu proses terencana guna menciptakan suatu perubahan kearah yang lebih baik dengan cepat, serta dapat memberikan berbagai macam perubahan kemajuan dalam segala bidang aspek bagi masyarakat (Pratama, 2013). Riyadi dalam (Mardikanto \& Soebiato, 2013), juga mendefinisikan pembangunan yaitu merupakan usaha atau proses perubahan, untuk tercapainya suatu tingkat kesejahteraan dan mutu hidup kelompok masyarakat atau individu didalamnya yang berkeinginan serta melaksanakan pembangunan. Pembangunan yang dimaksud yaitu pembangunan secara menyeluruh baik dari segi sosial, ekonomi, politik, keamanan dan pertahanan. Pembangunan tidak hanya membantu memenuhi sarana dalam bentuk nyata seperti bangunan, jembatan, jalan ataupun bantuan sesaat yang diberikan pada masyarakat. Pembangunaan hendaknya juga memperhatikan kualitas sumber daya manusianya, dengan meningkatkan kualitas sumber daya manusia (SDM) untuk menjadi mandiri dengan keterampilan yang dimiliki, secara tidak langsung akan membantu mereka keluar dari jerat kemiskinan (Anwas, 2014). Maka faktor utama dari kemiskinan juga terletak pada kualitas SDM suatu daerah, yang mana menjadi fokus perhatian penelitian ini. Perbaikan kualitas masyarakat dapat dilakukan dengan cara pemberdayaan pada masyarakat, dengan memberikan pengetahuan dan pelatihan agar mereka dapat mengembangkan diri.

Pemberdayaan merupakan upaya yang bisa dilakukan untuk memfasilitasi masyarakat lokal dalam mengelola sumberdaya yang dimilik. Selain itu pemberdayaan juga merupakan suatu upaya mendorong masyarakat untuk mampu menjadi sosok utama dalam memanfaatkan lingkungannya guna mencapai suatu 


\section{JURNAL ABDIMAS

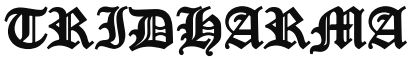 AtA:}

P-ISSN 2615-6849, E-ISSN 2716-070X

Jurnal ABDIMAS Vol. 2,No.3, Agustus 2021,Hal(10-17)

@ Prodi Manajemen Fakultas Ekonomi Universitas Pamulang

Email: abdimasjurnal.unpam@ gmail.com Telp: (021) 741-2566

\begin{abstract}
keberlanjutan untuk jangka panjang (Priatama, 2013).Seperti yang diungkapkan Santoso (2016) bahwa, pemberdayaan dengan kualitas masyarakatnya yang mandiri bisa menjadi sumbangan dalam kemajuan pembangunan nasional.
\end{abstract}

Pengenalan teknologi menjadi penting dalam upaya peningkatan pelaksanaan pemberdayaan masyarakat yang ditujukan kepada para masyarakat yang masih tradisional. untuk itu perlu solusi yang tepat yang dapat digunakan dalam pengelolaan sumber daya manusia yang sesuai dengan kebutuhan masyarakat, dapat menjawab permasalahan masyarakat, serta menghasilkan nilai tambah. Penelitian yang telah dilakukan sebelumnya menunjukkan bahwa pemberadayaan masyarakat dapat menjaga pembangunan berkelanjutan.

Penelitian dari (Rahmiyati, Andayani, \& Panjaitan, 2015) menunjukkan bahwa pemberdayaan masyarakat dapat memperbaiki ekonomi serta meningkatkan produktivitas serta mutu produksi. Usaha memberdayakan masyarakat ialah langkah untuk memandirikan serta memampukan masyarakat sehingga akan muncul perubahan yang efektif. Dalam proses usaha tersebut maka diperlukan teknologi yang tepat serta relevan sesuai kebutuhan kelompok masyarakat. Ketidak tepatan teknologi yang diimplementasikan pada masyarakat akan menimbulkan masalah, karena tidak sesuai dengan kondisi lokasi pemberdayaan. Dari penelitian diatas dapat dilihat, peran pada masyarakat, sebagai alat yang dapat menjaga pembangunan berkelanjutan dan dapat membantu dalam pembangunan. Namun dalam penelitian terdahulu menunjukkan hasil, masih kurangnya fasilitator dan juga pendampingan dari pihak-pihak pemberdaya seperti pemerintah dan juga lembaga pemberdayaan.

Dalam pengabdian ini akan memfokuskan pada pihak pemberdaya. Komunikasi sangat diperlukan dalam proses pemberdayaan yang melibatkan masyarakat, penentuan strategi komunikasi pemberdaya harus disesuaikan dengan keadaan masyarakatnya. Untuk keberhasilan program dibutuhkan pendeketan secara langsung, tatap muka dengan masyarakat sasaran. Pemberdaya melakukan komunikasi secara face to face pada masyarakat agar program yang diinginkan dapat diterima melalu penjelasan yang disampaikan. Selain itu diadakan juga pertemuan atau rembug warga, untuk memberikan penjelasan secara rinci dari program yang diadakan. Dalam perkembangannya banyak sekali program pengembangan seperti lokakarya dan training of trainer dilaksanakan, tentu pegawai kelurahan pamulang barat harus technology minded. artinya kantor kelurahan pamulang barat terkoneksi internet, pun sdm kelurahan pamulang barat harus "melek IT". oleh karena itulah, operator harus juga giat mendalami internet, social media dan blog sebagai alat dalam optimalisasi kinerja di kelurahan pamulang barat.

\section{RUMUSAN MASALAH}

Sejalan dengan perkembangan pendidikan yang semakin berkembang dan menjadi salah satu pintu utama kemajuan suatu bangsa. Dunia globalisasi mengakibatkan persaingan dalam bidang intelektual, teknologi, ekonomi, budaya, dsb.Sehingga pendidikan yang saat ini berjalan merupakan salah satu persaingan global. Pendidikan merupakan salah satu aspek penting yang harus di kembangkan sesuai dengan kemampuan intelektual umum yang memadai. Pembentukan dan pengembangan Kelurahan Pamulang Barat adalah menjembatani masyarakat pengguna teknologi, memberikan kemudahan kepada masyarakat dalam memperoleh pelayanan tehnis, pelayanan informasi dan promosi kepada masyarakat. Meningkatkan kerjasama dan koordinasi antar pemangku kepentingan dalam rangka pemanfaatan teknologi. 


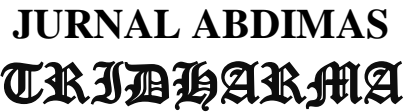 \\ JURNAL ABDIMAS

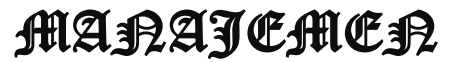

Kegiatan Pendidikan dan Pelatihan Penguatan Pegawai Kelurahan Pamulang Barat, bertujuan memberikan pemahaman bagi Pegawai Kelurahan Pamulang Barat dalam memberdayakan dan mengembangkan Sumber Daya Manusia, meningkatkan pengetahuan tentang peningkatan kapasitas serta ketrampilan managemen pengelolaan di Kelurahan Pamulang Barat. Metode pembelajaran dalam kegiatan penyelenggaraan pendidikan dan pelatihan penguatan Posyantek ini adalah, teori, tanya jawab dan diskusi. Materi yang akan disampaikan strategi membangun desa dengan tehnologi tepat guna, pedoman umum pengembangan SDM, penguatan pemberdayaan SDM di Kelurahan Pamulang Barat

Berdasarkan latar belakang tersebut, maka permasalahan dalam pengabdian ini dapat dirumuskan sebagai berikut :

1. Masih belum tercapainya target Kelurahan Pamulang Barat dalam meningkatkan kinerja pegawai Kelurahan Pamulang Barat.

2. Masih kurang optimalnya pelayanan di Kelurahan Pamulang Barat dalam melayani masyarakat sekitar.

\section{TUJUAN PELAKSANAAN}

Tujuan kegiatan dalam pengabdian Bidang Pengembangan Sumber Daya Manusia ini antara Lain:

1. Membangun dan mengembangkan potensi Sumber Daya Manusia yang mampu berkiprah dalam pembangunan dan mengikuti perkembangan teknologi

2. Menciptakan situasi kondusif bagi kegiatan pengabdian pada masyarakat

3. Mendukung pembangunan dan pengembangan Pemerintah Daerah dan membantu mencari solusi untuk mengatasi berbagai kendala khususnya dalam bidang IPTEKS

\section{TINJAUAN PUSTAKA}

\section{Pengertian Manajemen}

Pengertian manajemen secara umum dapat disimpulkan dari beberapa definisi menurut beberapa ahli. Hal ini dikarenakan banyak versi definisi manajemen. Contohnya saja manajemen menurut seorang ahli bernama Mary Parker Follet yang mendefinisikan manajemen sebagai seni merampungkan pekerjaan melalui orang lain. Dari definisi tersebut didapati bahwa seseorang yang bertugas sebagai manajer dapat mengarahkan dan mengatur orang lain guna mencapai tujuan organisasi.

Di sisi lain, James A.F Stoner mendefinisikan manajemen sebagai proses pengorganisasian, perencanaan dan penggunaan SDM supaya mencapai tujuan organisai yang sudah ditetapkan.

Secara umum, pengertian manajemen merupakan suatu seni dalam ilmu dan pengorganisasian seperti menyusun perencanaan, membangun organisai dan pengorganisasiannya, pergerakan serta pengendalian atau pengawasan. Bisa juga diartikan bahwa manajemen merupakan suatu ilmu pengetahuan yang sistematis agar dapat memahami mengapa dan bagaimana manusia saling bekerja sama agar dapat menghasilkan sesuatu yag bermanfaat bagi orang lain maupun golongan tertentu dn masyarakat luas.

Secara etimologis, pengertian manajemen merupakan seni untuk melaksanakan dan mengatur. Manajemen juga dapat dilihat sebagai ilmu yang mengajarkan proses mendapatkan tujuan dalam organisai, sebagai usaha bersama dengan beberapa orang dalam organisasi tersebut. Sehingga, ada orang yang merumuskan dan melaksanakan tindakan manajemen yang disebut dengan manajer.

\section{Fungsi Manajemen}




\section{JURNAL ABDIMAS

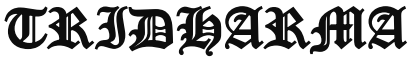 AtA:}

P-ISSN 2615-6849, E-ISSN 2716-070X

Jurnal ABDIMAS Vol. 2,No.3, Agustus 2021,Hal(10-17)

@ Prodi Manajemen Fakultas Ekonomi Universitas Pamulang

Email: abdimasjurnal.unpam@ gmail.com Telp: (021) 741-2566
Pada dasarnya, fungsi manajemen dibagi menjai tiga, yaitu :

a. Perencanaan (planning)

Perecanaan adalah memikirkan apa yang akan dikerjakan dengan sumber yang dimiliki. Perencanaan dilakukan untuk menentukan tujuan perusahaan secara keseluruhan dan cara terbaik untuk memenuhi tujuan itu. Manajer mengevaluasi berbagai rencana alternative sebelum mengambil tindakan dan kemudian melihat apakah rencana yang dipilih cocok dan dapat digunakan umtuk memenuhi tujuan perusahaan. Perencanaan merupakan proses terpenting dari semua fungsi manajemen karena tanpa perencanaan, fungsi-fungsi lainnya tak dapat berjalan.

b. Pengorganisasian (organizing)

Pengorganisasian dilakukan

dengan tujuan membagi suatu kegiatan besar menjadi kegiatan-kegiatan yang lebih kecil. Pengorganisasian mempermudah manajer dalam melakukan pengawasan dan menentukan orang yang dibutuhkan untuk melaksanakan tugastugas yang telah dibagi-bagi tersebut. Pengorganisasian dapat dilakukan dengan cara menentukan tugas apa yag harus dikerjakan, siapa yang harus mengerjakan, bagaimana tugas-tugas tersebut dikelompokkan, siapa yang bertanggungjawab atas tugas tersebut, dan pada tingkatan mana keputusan harus diambil.

c. Pengarahan (directing)

Pengarahan adalah suatu tingakan untuk mengusahakan agar semua anggota kelompok berusaha agar dapat mencapai sasaran sesuai dengan perencanaan manajerial dan usaha.

Setiap perusahaan memiliki unsur-unsur untuk membentuk system manajerial yang baik. Unsur-unsur inilah yang disebut unsur manajemen. Jika salah satu diantaranya tidak sempurna atau tidak ada maka akan berimbas dengan berkurangnya upaya untuk mencapai tujuan.

\section{Kinerja}

Kinerja merupakan tingkat produktivitas seorang karyawan, relative pada rekan kerjanya, pada beberapa hasil dan prilaku yang terkait dengan tugas. Kinerja dipengaruhi oleh variabel yang terkait dengan pekerjaan meliputi rolestress dan konflik kerja / non-kerja (Riani, 2013:61).

Pengertian lain mengenai kineja diungkapkan oleh As'ad (1998:47) dalam Riani (2013:61) menyatakan bahwa kinerja adalah hasil yang dicapai oleh seseorang menurut ukuran yang berlaku untuk pekerjaan yang bersangkutan.

Kinerja seseorang merupakan kombinasi dari kemampuan, usaha dan kesempatan yang dapat dinilai dari hasil kerjanya (Rosidah, 2009:276). Kinerja individu dipengaruhi oleh usaha (effort), kemampuan (ability) dan situasi lingkungan (Subhki dan Jauhar, 2013:41).

Russsell dalam Rosidah (2009:276) menyatakan bahwa kinerja merupakan catatan out-come yang dihasilkan dari fungsi pegawai tertentu atau kegiatan yang dilakukan selama periode waktu tertentu. Kinerja suatu jabatan secara keseluruhan sama dengan jumlah (rata-rata) dari kinerja fungsi pegawai atau kegiatan yang dilakukan (Rosidah, 2009:276). Menurut Ivancevich M. John (2007:85) dalam Wijaya (2012:2) kinerja individu merupakan pondasi kinerja organisasi. Faktor penting dalam keberhasilan suatu organisasi adalah adanya karyawan yang mampu dan terampil serta mempunyai semangat kerja yang tinggi, sehingga dapat diharapkan suatu hasil kerja yang memuaskan. Kenyataannya tidak semua karyawan mempunyai kemampuan dan ketrampilan serta semangat kerja sesuai dengan harapan organisasi. Seorang karyawan yang mempunyai kemampuan sesuai dengan harapan organisasi, kadangkadang tidak mempunyai semangat kerja tinggi sehingga kinerjanya tidak sesuai dengan yang diharapkan. (Sumarsono, 2004:168) dalam Wijaya (2012:2). 


\section{JURNAL ABDIMAS

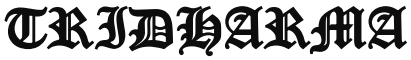 \\ AtA:}

P-ISSN 2615-6849, E-ISSN 2716-070X

Jurnal ABDIMAS Vol. 2,No.3, Agustus 2021,Hal(10-17)

@ Prodi Manajemen Fakultas Ekonomi Universitas Pamulang

Email: abdimasjurnal.unpam@gmail.com Telp: (021) 741-2566

\section{METODE PELAKSANAAN}

Metode kegiatan ini berupa pelatihan kepada pegawai kelurahan tentang MANAJEMEN PENGELOLAAN SUMBER DAYA MANUSIA DI KELURAHAN PAMULANG BARAT dan diharapakan dapat memberikan motivasi bagi para pegawai kelurahan. Metode kegiatan yang digunakan adalah melalui kunjungan langsung ke Kelurahan Pamulang Barat, Tangerang Selatan, dengan memberikan seminar, pelatihan dan pendampingan terhadap pegawai kelurahan yang ada dilingkungan Kelurahan Pamulang Barat.

Dalam pelatihan ini peserta pelatihan dan training diberikan materi tentang ketrampilan dalam kecakapan IT agar dapat mendukung optimalisasi kelurahan. Dengan pelatihan dan training ini diharapakan pengurus dapat meningkatkan produktivitasnya sehingga sasaran-sasaran dari kelurahan sendiri dapat tercapai.

Rencana pelaksanaan kegiatan adalah sebagai berikut.

Tempat : LPM Kelurahan Pamulang

Barat

Waktu Pelaksanaan Kegiatan : 29 - 31

Maret 2021

Berikut ini adalah tahapan pelatihan yang dilakukan :

1. Tahap Persiapan

Tahap persiapan yang dilakukan meliputi :

a. Survei awal, pada tahap ini dilakukan survei di dua tempat yaitu survei ke lokasi

b. Pemantapan dan penentuan lokasi dan sasaran. Setelah survei maka ditentukan lokasi pelaksanaan dan sasaran peserta kegiatan.

c. Penyusunan bahan/materi pelatihan yang meliputi: Slide dan makalah untuk kegiatan pelatihan ilmu manajemen.

2. Tahap Pelaksanaan Pelatihan
Tahap ini akan menitikberatkan pada pemberian penjelasan mengenai bagaimana MANAJEMEN PENGELOLAAN SUMBER DAYA MANUSIA DI KELURAHAN PAMULANG BARAT

1. Tahap Pelatihan

Untuk melaksanakan kegiatan tersebut digunakan beberapa metode pelatihan, yaitu :

a. Metode Ceramah

Metode ceramah dipilih untuk memberikan penjelasan tentang ilmu manajemen khususnya mengenai pemasaran

b. Metode Tanya Jawab

Metode tanya jawab sangat penting bagi para peserta pelatihan. Metode ini memungkinkan para peserta dapat menggali pengetahuan sebanyakbanyaknya tentang MANAJEMEN PENGELOLAAN SUMBER DAYA MANUSIA DI KELURAHAN PAMULANG BARAT

c. Metode Simulasi

Metode simulasi ini diberikan kepada para peserta pelatihan dalam memberikan kesempatan untuk mempraktekkan materi yang diperoleh..

\section{HASIL DAN PEMBAHASAN}

Pengabdian Kepada Masyarakat (PKM) Universitas Pamulang dilakukan oleh dosen-dosen program studi Manajemen telah berjalan dengan lancar dan mendapat sambutan hangat dari para peserta kegiatan ini yaitu para para pegawai kelurahan pamulang barat.

Dengan uraian yang diatas maka dengan adanya sebuah sistem yang terbentuk dan didalamnya terdiri dari tim yang solid, maka sebuah organisasi akan bisa bertahan walau dalam keadaan perekonomian yang sulit sekalipun. Dengan pengembangan SDM dan pengolahan SDM yang tepat dapat selalu mengatasi permasalah - permasalahan yang akan timbul di organisasi. Mampu terus berkembang Menciptakan sebuah pondasi yang kuat adalah kunci kesuksesan 


\section{JURNAL ABDIMAS

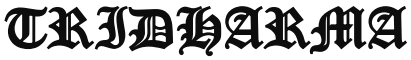 AtA:}

P-ISSN 2615-6849, E-ISSN 2716-070X

Jurnal ABDIMAS Vol. 2,No.3, Agustus 2021,Hal(10-17)

@ Prodi Manajemen Fakultas Ekonomi Universitas Pamulang

Email: abdimasjurnal.unpam@gmail.com Telp: (021) 741-2566 sebuah organisasi untuk dapat terus berkembang dengan pesat dan bisa bersaing di dalam dunia bisnis.

Merasa selalu tidak puas dengan kondisi yang ada akan selalu berfikir bagaimana untuk melakukan hal yang terbaik. Memperkokoh hubungan antar tim kerja sekaligus dalam upaya keterbukaan informasi yang ada didalamnya. Update informasi kepada seluruh karyawan yang selalu dilakukan sesuai dengan jadwal yang telah disepakati bersama. Selalu mendengar keluhan Sebuah keluhan akan selalu muncul dari berbagai pihak, keluhan-keluhan tersebut bukan sebagai penghambat akan tetapi untuk terus meningkatkan pelayanan.

Secara tidak sengaja maka akan dapat membantu permasalahan Bangsa ini dalam menghadapi berbagai kesulitan yang akan timbul. Karena peningkatan SDM sifatnya adalah menularkan ke sesama manusia yang ada disekitar dan saling membantu satu sama lain yang dapat menjadikan Bangsa ini tumbuh dan berkembang. Lingkungan Sekitar Dapat memberikan manfaat kepada lingkungan sekitar yang dampaknya dapat dirasakan secara nyata. Hal ini menyebabkan organisasi secara tidak langsung berperan aktif dalam hal pengembangan SDM demi kemajuan bangsa. SDM yang mampu bersaing pada kompetisi global Pembuktian yang nyata dalam pengembangan SDM yang mampu bersaing secara global yaitu dengan cara mengikutsertakan pegawai dalam ajang kompetisi tingkat dunia. Hal tersebut memberikan kontribusi secara nyata kepada Bangsa dan Negara..

\section{KESIMPULAN DAN SARAN Kesimpulan}

Terdapat 3 aspek yang perlu di perhatikan dalam pengelolaan manajemen SDM ini yaitu: Kebutuhan organisasi, Kebutuhan unit serta Kebutuhan individu. Suatu organisasi harus mengidentifikasi kebutuhan pengembangan yang sesuai dengan kecenderungan strategi organisasi, .dengan demikian pebgembangan yang dilalsanakan dapat diaplikasikan dalam organisasi pada saat itu karena jenis pengenmbangan yang dilaksanakan merupakan jenis yang dibutuhkan saat itu sehingga pegawai tidak ketinggalan. Kebutuhan unit akan kompetensi SDM yang dibutuhkan perlu dikaji begiru juga dengan kebutuhan individu tersebut.

\section{DAFTAR PUSTAKA}

Andini, R., Syah, A., Sulistiani, S., Yusran, Y., \& Septiani, Y. (2020). PENGENALAN STRATEGI PEMASARAN PETERNAKAN AYAMGUNA MENINGKATKAN LABA PADA UKM DIDESA JUN REJO, JAWA TIMUR. Jurnal Lokabmas Kreatif: Loyalitas Kreatifitas Abdi Masyarakat Kreatif. https://doi.org/10.32493/jlkklkk.v1i1. p50-55.5595

A.F. Stoner. 2006. Manajemen Sumber Daya Manusia. Jakarta: Bumi Aksara.

A.A. Anwar Prabu Mangkunegara. 2007. Manajemen Sumber Daya Manusia. Cetakan Ke Tujuh. Bandung : PT. Remaja Rosdakarya

Dessler Gary. 2014. Manjemen Sumber Daya Manusia. Edisi Kesembilan. Jilid II. Jakarta: PT. Indeks

Elburdah, R. P., Pasaribu, V. L. D., Rahayu, S., Septiani, F., \& Metarini, R. R. A. (2021). Mompreneur Penopang Perekonomian Keluarga Di Masa Pandemi Covid-19 Dengan Bisnis Online Pada Kelurahan Pondok Benda. Abdi Laksana: Jurnal Pengabdian Kepada Masyarakat, 2(1), 75-82.

Handayaningrat, Soewarno. 1992. Pengantar Studi Ilmu Administrasi dan Manajemen. Jakarta: $\mathrm{Cv}$ Haji Masagung. 


\section{JURNAL ABDIMAS

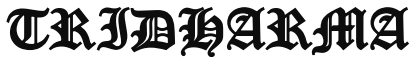 \\ AIA:}

P-ISSN 2615-6849, E-ISSN 2716-070X

Jurnal ABDIMAS Vol. 2,No.3, Agustus 2021,Hal(10-17)

@ Prodi Manajemen Fakultas Ekonomi Universitas Pamulang

Email: abdimasjurnal.unpam@ gmail.com Telp: (021) 741-2566
Handoko,T. Hani. 2001. Manajemen Edisi Kedua. Yogyakarta: BPFE.

Hasibuan, Malayu S P. 2004. Manajemen, Dasar, Pengertian dan Masalah. Bandung: Bumi Aksara.

Hulasoh, E., Syamsuddin, R. A., Praditya, A., Lisdawati, \& Supardi. (2020). Pengaruh Gadget Terhadap Prestasi Belajar Remaja Di Era Milenial Pada Lembaga Bimbingan Belajar Daarul 'Uluum Petukangan Utara, Pesanggrahan, Jakarta Selatan. ABDIMAS.

Pratama, A., \& Syamsuddin, R. A. (2020). DAMPAK KOMITMEN ORGANISASI ATAS KINERJA KARYAWAN PT BNI KCP PAMULANG. ProBank. https://doi.org/10.36587/probank.v5i $\underline{2.723}$

Pasaribu, V. L. D., Agrasadya, A., Shabrina, N., \& Krisnaldy, K. (2020). Menjadi Enterpreneur Muda Yang Memiliki Jiwa Leadership Untuk Menghadapi Masa Depan. Abdi Laksana: Jurnal Pengabdian Kepada Masyarakat, 1(1).

Pasaribu, V. L. D., Susanti, F., \& Hartuti, E. T. K. (2019). Memotivasi Siswa dan Siswi SMK Letris Indonesia di Dalam Menentukan Pilihan Untuk Melanjutkan Pendidikan Atau Bekerja Setelah Lulus Sekolah. Jurnal Pengabdian Dharma Laksana, 1(2), 161-172.

Pasaribu, V. L. D., Sulaiman, S., Sutiman, S., Thaharudin, T., \& Purnomo, B. Y. (2020). Pengenalan Letak Posyandu Terdekat Dikelurahan Pisangan Dengan Manajemen Pemasaran Revolusi 4.0 Untuk Meningkatkan Pengetahuan Masyarakat Letak Dan Fungsi Posyandu Terdekat Pada Kelurahan Pisangan. Dedikasi Pkm, 1(1), 105-110.

Pasaribu, V. L. D., Oktrima, B., Prabowo, B., Arianto, N., \& Haryoko, U. B. (2020).
Progam Pendampingan Dan Penyelenggaraan Pendidikan Anak Pada Usia Dini Terhadap Prestasi Belajar Dilingkungan Rt 020 Rw 009. Kel Giri Peni. Kec Wates. Yogyakarta. Jurnal Lokabmas Kreatif, 1(1), 71-75.

Pasaribu, V. L. D., Jannah, M., Fazar, M., Putra, S. P., Monalisa, M., \& Sofa, M. (2021). MENINGKATKAN PRODUKTIVITAS USAHA DIMASA PANDEMI PADA IBU PKK RT 004/003 KELURAHAN SAWAH BARU CIPUTAT, TANGERANG SELATAN. Abdi Laksana: Jurnal Pengabdian Kepada Masyarakat, 2(2), 295-301.

Pasaribu, V. L. D., Yuniati, H. L., Pranata, R., Sembayu, R., Purba, S. M., \& Nurbayani, T. T. A. (2021). MANAJEMEN KEUANGAN UNTUK MENGHADAPI DAN BERTAHAN DI ERA COVID 19. Jurnal Abdimas Tri Dharma Manajemen, 2(2), 12-18.

Pasaribu, V. L. D., Dwiyatni, A., Sabina, C., Ridwan, M., Gunawan, D. D., \& Noviani, B. C. (2021). EVALUASI PENERAPAN 3M DIMASA PANDEMIC COVID 19. Jurnal Abdimas Tri Dharma Manajemen, 2(2), 54-60.

Pasaribu, V. L. D., Syafei, A. N., Farhan, A., Aufaizah, A., Irani, C., \& Firtiayani, S. R. (2021). PENGARUH DISPLIN PROTOKOL KESEHATAN TERHADAP PENCEGAHAN PENULARAN VIRUS COVID19. Jurnal Abdimas Tri Dharma Manajemen, 2(2), 91-98.

Priadi, A., Pasaribu, V. L. D., Virby, S., Sairin, S., \& Wardani, W. G. (2020). Penguatan Ekonomi Kreatif Berbasis Sumber Daya Desa Dikelurahan Rempoa. Abdi Laksana: Jurnal Pengabdian Kepada Masyarakat, 1(3), 356-35

Rahmi Andini Syamsuddin, Lisdawati, \& Agung Tri Putranto. (2020). Evaluation Performance of Social Organization in Setu District - South Tangerang. Jurnal Ekonomi \& Bisnis 


\section{JURNAL ABDIMAS

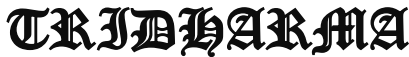 AIA}

P-ISSN 2615-6849, E-ISSN 2716-070X

Jurnal ABDIMAS Vol. 2,No.3, Agustus 2021,Hal(10-17)

@ Prodi Manajemen Fakultas Ekonomi Universitas Pamulang

Email: abdimasjurnal.unpam@gmail.com Telp: (021) 741-2566
JAGADITHA.

https://doi.org/10.22225/jj.7.2.2483.1 $\underline{23-127}$

Utomo, H. (2014). Menumbuhkan Minat Kewirausahaan Sosial (Hardi Utomo). Kewirausahaan

Siagian, P Sondang. 1992. Fungsi-fungsi Manajerial. Jakarta: Bumi Aksara.

Singarimbun, Masri dan Sofian Efendi. 1987. Metode Penelitian Survai. Jakarta: LP3ES.

Siswanto, H.B. 2005. Pengantar Manajemen. Jakarta: Bumi Aksara.

Susanti, F., Lisdawati, L., Andini, R., Setiawan, R., \& Ratnawati, W. (2020). MENANAMKAN JIWA DAN SEMANGAT

KEWIRAUSAHAAN

PERSAINGAN MENGHADAPI DI ERA GLOBALISASI PADA GURU DAN ORANGTUA MURID BIMBINGAN BELAJAR BIMBA PAMULANG TANGERANG SELATAN. DEDIKASI PKM. https://doi.org/10.32493/dedikasipkm . v1i1.6061

Syamsuddin, R. A., \& Lisdawati, L. (2020). Kinerja Dinas Pengendalian Penduduk, Keluarga Berencana dan Pemberdayaan

Perempuan, Perlindungan Anak (DP2KBP3A) dalam Menangani Kasus Kekerasan pada Perempuan dan Anak di Kabupaten Pandeglang, Banten Tahun 2020. Jurnal Apresiasi Ekonomi.

https://doi.org/10.31846/jae.v8i3.319

Tanaka, Nao. 2012. Teknologi Tepat Guna \& Dunia Alternatif. Jakarta: PT Bhuana Ilmu Populer.
Terry, G.R dan L.W Rue. 1992. DasarDasar Manajemen. Jakarta: Bumi Aksara.

Tunggal, Amin Widjaja. 2002. Manajemen suatu pengantar. Jakarta: Rineka Cipta.

\section{DOKUMENTASI FOTO KEGIATAN}
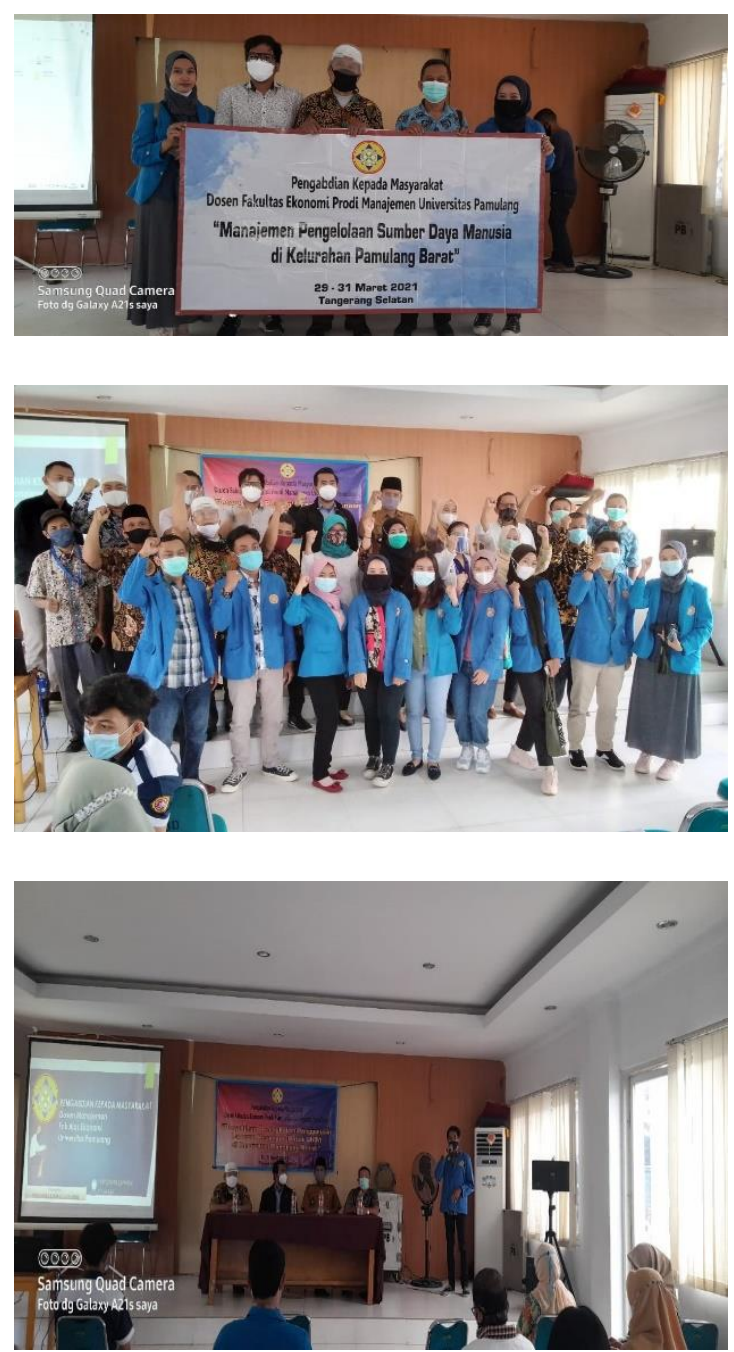


\section{JURNAL ABDIMAS

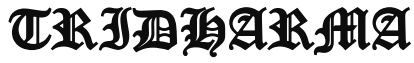

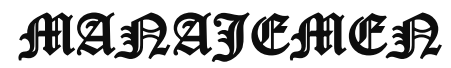

P-ISSN 2615-6849, E-ISSN 2716-070X

Jurnal ABDIMAS Vol. 2,No.3, Agustus 2021,Hal(10-17)

@Prodi Manajemen Fakultas Ekonomi Universitas Pamulang

Email: abdimasjurnal.unpam @gmail.com Telp: (021) 741-2566 